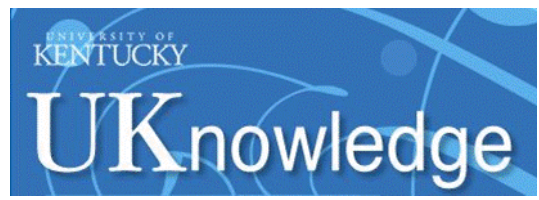

University of Kentucky

UKnowledge

\title{
The Role of the Leukemia Inhibitory Factor Receptor in Neuroprotective Signaling
}

\author{
Stephanie M. Davis \\ University of Kentucky, stephanie.davis@uky.edu \\ Keith R. Pennypacker \\ University of Kentucky, keith.pennypacker@uky.edu
}

Follow this and additional works at: https://uknowledge.uky.edu/catss_facpub

Part of the Neurology Commons, and the Neurosciences Commons

Right click to open a feedback form in a new tab to let us know how this document benefits you.

\section{Repository Citation}

Davis, Stephanie M. and Pennypacker, Keith R., "The Role of the Leukemia Inhibitory Factor Receptor in Neuroprotective Signaling" (2018). Center for Advanced Translational Stroke Science Faculty Publications. 1.

https://uknowledge.uky.edu/catss_facpub/1

This Article is brought to you for free and open access by the Center for Advanced Translational Stroke Science at UKnowledge. It has been accepted for inclusion in Center for Advanced Translational Stroke Science Faculty Publications by an authorized administrator of UKnowledge. For more information, please contact UKnowledge@lsv.uky.edu. 


\section{The Role of the Leukemia Inhibitory Factor Receptor in Neuroprotective Signaling \\ Digital Object Identifier (DOI)}

https://doi.org/10.1016/j.pharmthera.2017.08.008

Notes/Citation Information

Published in Pharmacology \& Therapeutics, v. 183.

(c) 2017 Published by Elsevier Inc.

(๑) 2017. This manuscript version is made available under the CC-BY-NC-ND 4.0 license

https://creativecommons.org/licenses/by-nc-nd/4.0/.

The document available for download is the authors' post-peer-review final draft of the article. 


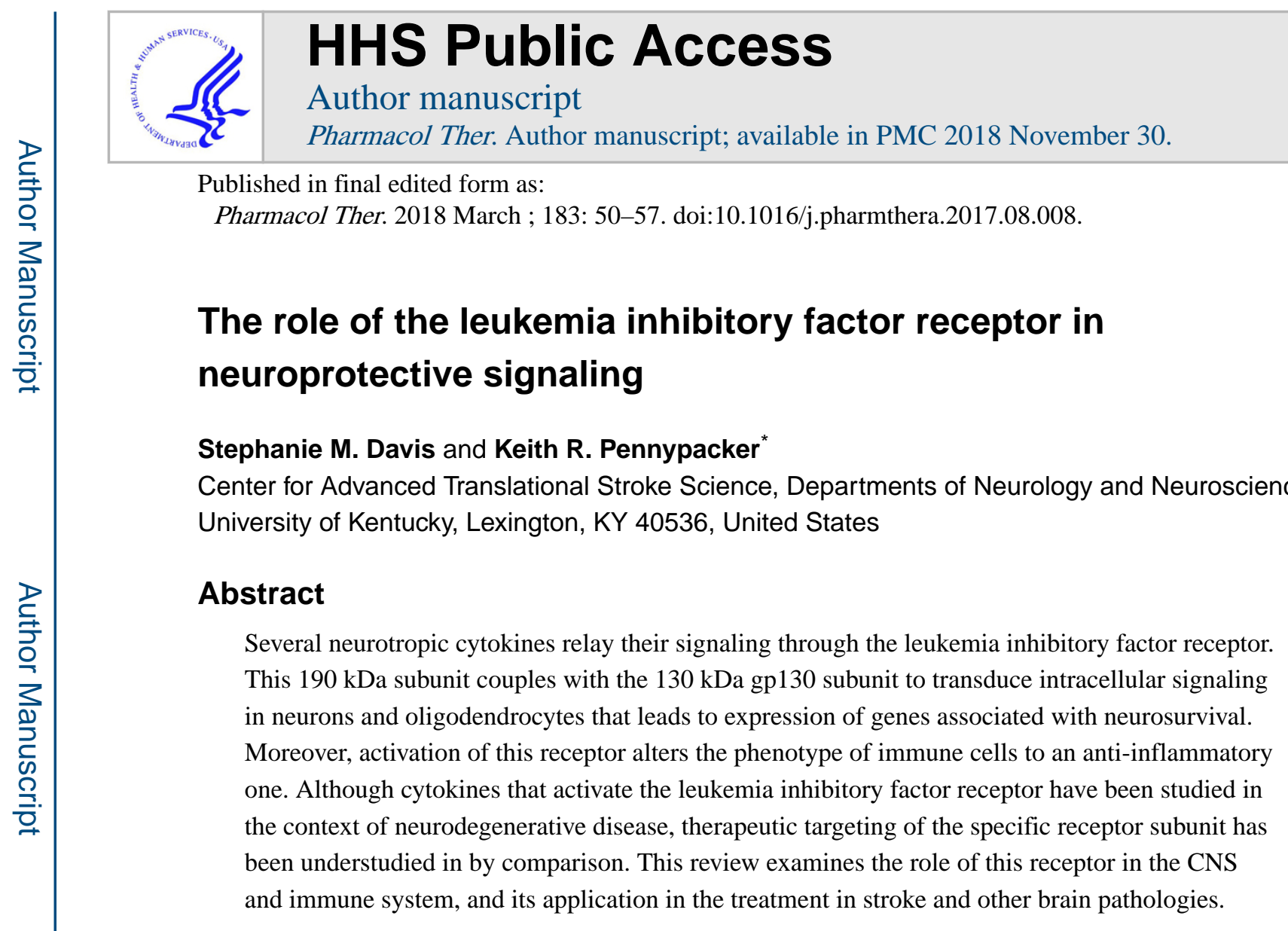

\section{Keywords}

Cytokine; Signal transduction; Brain injury; Inflammation

\section{Introduction}

The leukemia inhibitory factor receptor (LIFR) is a $190 \mathrm{kDa}$ member of the type 1 cytokine receptor family (Gadina et al., 2001). The activation of this receptor relays intracellular signals that result in enhanced cellular survival in neural cells and altering the phenotype of $\mathrm{T}$ cells and macrophages from an inflammatory to an anti-inflammatory one. In brain injury, such as stroke, neural cell survival signaling is necessary to protect cells (Rowe et al., 2012). Additionally, the immune system, which mounts an inflammatory neurodegenerative response to the brain injury, needs to be diverted towards an anti-inflammatory state (Ajmo et al., 2008; Offner et al., 2006). Signaling via LIFR provides both of these properties establishing this receptor as a valid therapeutic target for a treatment for stroke and other neurological injuries.

\section{Structure of LIFR}

Although LIFR was discovered prior to 1991, its structure was determined after Gearing et al. (1991) isolated LIFR transcripts from a cDNA library. This study demonstrated that LIFR

*Corresponding author at: Center for Advanced Translational Stroke Science, Departments of Neurology and Neuroscience, Building BBSRB, Office B457, University of Kentucky, Lexington, KY 40536, United States. keith.pennypacker@uky.com (K.R.

Pennypacker). 
is a $190 \mathrm{kDa}$ protein with three distinct regions: an extracellular domain of 789 amino acids, a transmembrane domain containing 26 amino acids, and a cytoplasmic domain containing 238 amino acid residues. In addition, the cytoplasmic and transmembrane domains shared several conserved regions with those of glycoprotein 130 (gp130), the high-affinityconverting subunit that is present in the receptors of all IL-6 family cytokines. According to the authors, the sequence homology between the two receptors may account for the fact that IL-6 and LIF activate similar signaling cascades and have overlapping downstream effects (Gearing et al., 1991).

LIFR exists in a soluble and membrane-bound forms depending upon which cDNA transcript is expressed in the cell. Tomida, Yamamoto-Yamaguchi, and Hozumi (1994) isolated RNA from the murine liver tissue and used RT-PCR to create cDNA transcripts of LIFR mRNAs. While the authors identified one of the cDNAs as the transcript coding for the membrane-bound LIFR, a second transcript was identified that contained a unique, 501 bp sequence. This sequence, which contained a stop codon, corresponded to the soluble form of LIFR, which lacked the transmembrane and cytoplasmic regions of the other LIFR variant. This soluble form of LIFR, alternatively known as LIF-binding protein (LBP), is upregulated during pregnancy and acts as an antagonist to serum LIF levels (Layton et al., 1992; Tomida et al., 1994).

Membrane-bound LIFR is widely expressed across several tissue types, but the expression of LBP is restricted mainly to the liver and the uterus. However, the expression of LIFR is controlled by two distinct promoter regions in a tissue-specific manner. The first promoter is $\mathrm{G} / \mathrm{C}$ rich and is associated with widespread, constitutive LIFR expression. A second promoter sequence controls expression of LIFR in the liver, but is also responsible for upregulation of uterine LIFR during pregnancy (Argetsinger et al., 1995; Owczarek, Layton, Robb, Nicola, \& Begley, 1996; Tomida et al., 1994).

\section{LIFR signaling}

LIFR confers its effects via association with other receptor subunits including the gp130 subunit, which is shared by all IL-6 family cytokine receptors (Gearing et al., 1991), the glycosyl-phosphatidylinositol (GPI) linked-ciliary neurotrophic factor receptor (CNTFR) (Davis et al., 1991), and the cardiotrophin-1 (CT-1) receptor. Cytokines in the IL-6 family exert downstream signaling through heterodimeric/hetero-trimeric receptor complexes that contain LIFR. LIF requires LIFR/gp130 for binding and receptor activation, while CNTF binds to a tripartite LIFR/CNTFR/gp130 complex. CT-1 also binds to the LIFR/gp130 heterodimer in addition to LIF, although the CT-1 receptor complex may contain a unique subunit not found in the LIF receptor complex (Bauer, Kerr, \& Patterson, 2007; Robledo et al., 1997). Oncostatin M (OSM) binds to the LIF receptor heterodimer in a species-specific manner. While OSM exerts signaling through either a gp130/OSMR complex or LIFR/ gp130 in humans, mouse OSM can only bind to gp130/OSMR (Gearing et al., 1992; Lindberg et al., 1998; Miyajima et al., 2000; Tanaka et al., 1999).

Upon cytokine binding, the receptor subunits associate with each other in addition to members of the Janus kinase (JAK) family. These JAKs undergo self-phosphorylation and 
phosphorylate the receptor subunits. Three main signaling pathways can be subsequently activated: Ras/MAPK/ERK, PI3K/Akt, and JAK/STAT signaling (Boulton, Stahl, \& Yancopoulos, 1994; Oh et al., 1998; Stahl et al., 1994; Stahl et al., 1995). The precise consequences of each signaling pathway differ between cell types, but one of the ways in which LIFR signaling exerts long-lasting effects is through changes in gene expression. In several embryonic stem cell lines, Ras/MAPK signaling upregulates genes involved in proliferation and self-renewal, JAK/STAT controls genes that regulate self-renewal, and PI3K/Akt signaling induces pro-survival genes (Binetruy, Heasley, Bost, Caron, \& Aouadi, 2007; Graf, Casanova, \& Cinelli, 2011; Majumder et al., 2012).

\section{Regulation of LIFR surface expression and trafficking}

In order to confer downstream signaling, LIFR must be localized to the plasma membrane and in close proximity to other IL-6 cytokine receptor components. According to Port et al., the association of receptor subunits in detergent-soluble membrane rafts occurs following stimulation with CNTF, but not LIF. Interestingly, the authors demonstrated that while mechanisms of membrane trafficking differ during CNTF and LIF stimulation, both cytokines failed to activate PI3K/Akt or Ras/MAPK signaling following treatment with $\beta$ cyclodextrin, a drug that depletes cholesterol from the membrane. These results suggest that CNTF and LIF signaling rely on lipid rafts for activation of these pathways, and that LIF might associate with rafts that are soluble in $1 \%$ Triton-X-100. Activation of STAT3 by CNTF/LIF occurred regardless of cholesterol depletion, indicating that STAT3 activity is not lipid raft-dependent. These differential mechanisms of LIFR trafficking may explain how CNTF and LIF, which normally signal through overlapping pathways, exert differential effects in certain cell lines, such as adipocytes and neuroblastoma lines (Johnson \& Nathanson, 1994; Ott et al., 2004; Port, Gibson, \& Nathanson, 2007).

According to several studies, mechanisms that terminate LIFR-dependent signaling are dependent upon cell type. Schiemann et al. (1995) discovered that prolonged stimulation of 3 T3-L1 cells with LIF triggered the endocytosis of LIFR. This process is dependent upon the phosphorylation of Serine 1044 on its cytoplasmic tail by ERK1/2 after prolonged stimulation with its ligand (Schiemann et al., 1995). A subsequent study by Blanchard et al. showed that phospho-LIFR undergoes lysosomal degradation following endocytosis. This effect was reversed upon treatment with chloroquine, an anti-malarial drug that inhibits lysosomes. However, inhibition of the proteasome did not reverse the decrease in LIFR protein expression, indicating that the cell degrades LIFR via the lysosomes (Blanchard et al., 2000).

Although LIFR is degraded following excessive stimulation with LIF in non-neural cell types, the surface expression of LIFR appears to be regulated via a different mechanism in neural cells. Gardiner, Cafferty, Slack, and Thompson (2002) showed that LIFR is localized to the nuclear region of sensory neurons under resting conditions. After surgical injury, LIFR was localized to the cytoplasmic and plasma membrane of the neuronal somata. Since LIFR requires association with gp130 at the membrane to confer downstream signaling, the trafficking of LIFR from the nucleus to the membrane is a neuroprotective mechanism against the injury (Gardiner et al., 2002). 


\section{The role of LIFR in nervous system development}

Constitutive expression of LIFR in multiple CNS cell types has been previously demonstrated by several independent groups. Patterson and Chun first showed that neurokine signaling through LIFR regulates cholinergic differentiation in sympathetic neurons (Chun \& Patterson, 1977). Subsequent investigation proved that LIFR plays a role in the differentiation of other neuronal populations including adrenergic and dopaminergic neuronal populations (Fan \& Katz, 1993; Lewis et al., 1994). In addition to its regulation of neuronal signaling, one of the most prominent roles played by LIFR involves the development and maturation of neurons and glia. Presence of LIF or ciliary neurotrophic factor (CNTF) stimulates the maturation of astrocytes from astrocytic progenitor cells. However, this effect was not observed following stimulation with IL-6, thus indicating that LIFR is necessary for normal astrocyte development (Yoshida, Satoh, Nakagaito, Kuno, \& Takeuchi, 1993). LIF and CNTF also promoted the development of mature oligodendrocytes from 0-2A + oligodendrocyte progenitor cells (OPCs) (Fischer, Wajant, Kontermann, Pfizenmaier, \& Maier, 2014; Mayer, Bhakoo, \& Noble, 1994). These factors also caused $0-2 \mathrm{~A}+$ OPCs to develop into type-2 astrocytes in vitro, but only in the presence of extracellular matrix proteins. Therefore, LIFR signaling yields several options for CNS cell development depending upon the presence of external factors (Gard, Burrell, Pfeiffer, Rudge, \& Williams, 1995). Neuronal development may either be enhanced or inhibited by LIFR signaling depending upon the neural subtype and external biochemical environment. Several groups demonstrated that knocking out the LIFR gene in mice yields a lethal defect in the development of motor neurons (DeChiara et al., 1995; Li, Sendtner, \& Smith, 1995; Ware et al., 1995). On the other hand, activation of LIFR through CNTF signaling appears to hinder the maturation of cortical neurons (Bonni et al., 1997). By contrast, in vitro studies published by Richards et al. show that antibodies against LIFR block the development of mature neurons. However, this phenomenon was limited to serum-free cultures, and the addition of serum promoted the development of astrocytes over neurons (Richards et al., 1996).

\section{Leukemia inhibitory factor}

Several cytokines that are involved with neurogenesis and gliogenesis utilize the LIFR subunit as a component of their receptor complexes. LIF exerts several important functions in the nervous system via activation of LIFR/gp130. According to Murphy, Reid, Hilton, and Bartlett (1991) treatment of mouse neural crest cells with LIF triggered the development of sensory neurons in vitro (Murphy et al., 1991). LIF also induces the development of neurons from precursor cells in the spinal cord (Richards, Kilpatrick, Bartlett, \& Murphy, 1992), and promotes neurogenesis in vitro when combined with CTNF, another IL-6 family neurokine (Galli, Pagano, Gritti, \& Vescovi, 2000). However, LIF exerts anti-neurogenic effects in the CNS by inhibiting the terminal differentiation of murine olfactory receptor neurons as well as neurons in the primary visual cortex (Engelhardt et al., 2017; Moon et al., 2002). LIF increases neural stem cell (NSC) populations and enhances self-renewal by inhibiting differentiation, which allows NSCs to aid in neural repair during injury (Bauer \& Patterson, 2006; Buono, Vadlamuri, Gan, \& Levison, 2012; Covey \& Levison, 2007). Using a gene microarray, Wright et al. demonstrated that these anti-differentiation effects on NSC 
populations following LIF treatment occurred due to changes in the expression of over 200 genes (Wright et al., 2003). LIF regulates the development of several glial cell populations in addition to neurons. LIF enhances proliferation of oligodendrocyte progenitor cells and increased the population of mature oligodendrocytes in the hippocampus during cuprizoneinduced demyelination (Deverman \& Patterson, 2012; Mayer et al., 1994). By contrast, LIF knockout mice exhibit delayed oligodendrocyte development and myelination in areas such as the optic nerve (Bugga, Gadient, Kwan, Stewart, \& Patterson, 1998; Ishibashi, Lee, Baba, \& Fields, 2009).

LIF, in conjunction with bone morphogenetic protein 2 causes NSCs to differentiate into astrocytes (Nakashima, Yanagisawa, Arakawa, \& Taga, 1999; Yoshida et al., 1993). However, the study by Koblar et al. shows that $L I F$ knockout mice show only a partial reduction in hippocampal astrocytes, while LIFR knockout mice show a complete deficiency (Koblar et al., 1998).

\section{Ciliary neurotrophic factor}

CNTFactivates downstream signaling pathways that are also targeted by LIF (i.e. PI3K/Akt, MAPK, and JAK/STAT) (Boulton et al., 1994). Therefore, CNTF confers similar effects on neural cell development/differentiation to LIF signaling. CNTF promotes the in vitro renewal of NSC populations in the forebrain through Notch1 signaling (Chojnacki, Shimazaki, Gregg, Weinmaster, \& Weiss, 2003; Hagg, 2005; Ip et al., 1992). Treatment of cortical precursor cells with CNTF also induces the formation of astrocytes via JAK/STAT activation (Bonni et al., 1997). CNTF administration promotes the in vitro survival and differentiation of oligodendrocyte progenitor cells into mature oligodendrocytes under physiological conditions and during white matter injury (M. Mayer et al., 1994; Pasquin, Sharma, \& Gauchat, 2015; Talbott et al., 2007; Tripathi \& Mctigue, 2008). Compared to LIF, CNTF is a stronger promoter of neurogenesis in vivo (Bauer et al., 2007). Emsley et al. demonstrated that CNTF signaling in the mouse forebrain promotes neurogenesis in the dentate gyrus and the subventricular zone. In addition, CNTF treatment yielded a mild increase in the number of astrocytes, but favored the formation of neurons in these regions. This study also suggested that the pro-neurogenic signaling of CNTF was dependent upon its ability to activate astrocytes in the sub-ventricular zone and dentate gyrus (Emsley \& Hagg, 2003). A report by Albrecht et al. confirmed this finding by demonstrating that CNTF increased motor neuron survival by stimulating astrocytes to release fibroblast growth factor-2 (Albrecht, Dahl, Stoltzfus, Levenson, \& Levison, 2002). In CNTF-deficient mice, the number of NSCs and rate of neurogenesis in the dentate gyrus was significantly reduced compared to wild-type mice. This phenotype was not observed in LIFknockout mice, thus suggesting a unique role for CNTF in neurogenesis (Müller, Chakrapani, Schwegler, Hofmann, \& Kirsch, 2009). In previous studies utilizing rat models, CNTFR was thought to be localized to neuronal cells, but not mature astrocytes. These conflicting results could be a consequence of species-specific differences in neurogenesis/gliogenesis (Emsley \& Hagg, 2003; Ip et al., 1993). 


\section{Cardiotrophin-1}

Barnabe-Heider et al. demonstrated that CT-1 induces the development of astrocytes from cortical precursor cells in vitro. According to their findings, CT-1 is released by immature neurons to facilitate the differentiation of cortical precursors into cortical astrocytes. The induction of astrogliogenesis depends upon the upregulation of LIFR and gp130 in cortical precursor cells between 0 and 8 days in vitro. Immature neurons within cultures of precursor cells will release endogenous CT-1 in order to promote the development of astrocytes and inhibit further development of neurons (Barnabé-Heider et al., 2005).

These studies demonstrate that LIFR is crucial for the development of neural cell population in the CNS. According to several independent groups, homozygous LIFR knockout mice exhibit defects in neural stem cell self-renewal, astrocyte development, and neurogenesis compared to wild-type mice. In spite of the overlapping roles of IL-6 family cytokines (i.e. LIF, CNTF, CT-1) in facilitating neurogenesis/gliogenesis, these processes are dependent upon the presence of LIFR and gp130 (Koblar et al., 1998; Li et al., 1995; Pitman et al., 2004; Shimazaki, Shingo, \& Weiss, 2001).

\section{Treatment of neurodegenerative disease}

\subsection{Neuroprotective effects of LIF}

Cytokines that signal through LIFR have shown strong potential in treating animal models of neurodegenerative disease. Under pathophysiological conditions, LIF is upregulated endogenously and released by several cells of the nervous system. Brain endothelial cells release LIF to promote the differentiation of astrocytes, which also secrete LIF to promote neuroprotective signaling (Banner, Moayeri, \& Patterson, 1997; Mi, Haeberle, \& Barres, 2001; Moidunny et al., 2012). Pericytes, which help comprise the BBB, have been tested as a therapeutic for myocardial infarction based on their ability to promote cardioprotection via secretion of LIF (Chen et al., 2013). NSC populations upregulate LIF mRNA following stimulation with interferon $\gamma$, which is produced by T lymphocytes and natural killer cells after stroke. This secretion of LIF promotes brain repair by acting on neural cells and by triggering proliferation of other NSCs (Felling, Covey, Wolujewicz, Batish, \& Levison, 2016; Laterza et al., 2013; Yilmaz, Arumugam, Stokes, \& Granger, 2006). Neurons also increase expression of LIF in response to injury. Getchell, Shah, Partin, Subhedar, and Getchell (2002) showed that olfactory receptor neurons upregulate LIF mRNA following targeted ablation, which may promote survival in an autocrine manner (Getchell et al., 2002).

Animal models of neurodegeneration show that LIF enhances survival of neural cells and promote regeneration of damaged tissue. Azari, Galle, Lopes, Kurek, and Cheema (2001) revealed LIF decreased the degradation of motor neurons in the G93A SOD1 mouse model of familial ALS and reduced white matter damage after spinal cord injury (Azari et al., 2001, 2003, 2006). Due to its pro-survival effects on oligodendrocytes, LIF has been explored as a therapeutic for demyelinating diseases, most notably the experimental allergic encephalomyelitis (EAE) model of multiple sclerosis. Following induction of EAE, oligodendrocytes upregulate LIFR in vivo, which appears to be an endogenous mechanism 
of sensitizing white matter to the protective effects of LIF (Butzkueven et al., 2002;

Butzkueven, Emery, Cipriani, Marriott, \& Kilpatrick, 2006; Laterza et al., 2013; Slaets et al., 2008). Recently, Rittchen et al. used LIF-encapsulated nanoparticles to promote remyelination in the CNS. These nanoparticles were labeled with antibodies against NG2, which allowed the authors to selectively target OPCs and stimulate white matter repair (Rittchen et al., 2015). LIF containing-nanoparticles have also been used to enhance the efficacy of cellular therapies. For instance, Dyson et al. demonstrated that coating fetal rat dopaminergic cells with LIF-containing nanoparticles reduced cellular death upon transplantation. This strategy may improve the use of dopaminergic cell grafts as a treatment for Parkinson's disease (Dyson, Fahmy, Metcalfe, \& Barker, 2014).

The ability of LIF to rescue gray and white matter from damage makes it a promising candidate for preclinical stroke studies, in which preventing neuronal and oligodendrocyte loss is crucial. Suzuki et al. showed that LIF activates its three main signaling pathways (MAPK, PI3K/Akt, and JAK/STAT) to promote neuroprotection after focal cortical injury (Suzuki et al., 2005). LIF treatment alone and in conjunction with fibroblast growth factor-2 increased the activity of antioxidant enzymes, including glutathione peroxidase and superoxide dismutase isoforms, and reduced oxidative damage. Other studies using the permanent middle cerebral artery occlusion model of stroke demonstrated that LIF confers direct neuroprotection through upregulation of antioxidant enzymes in oligodendrocytes and neurons (Davis et al., 2016; Rowe et al., 2014).

\subsection{CNTF increases cell survival in neurodegeneration models}

CNTF has shown similar efficacy in treating animal models of neurodegeneration. Modi et al. showed that in vitro administration of aspirin, which upregulates CNTF via PKA signaling, protected cultured oligodendrocytes against TNF-a, which facilitates the inflammatory response during multiple sclerosis (Modi, Sendtner, \& Pahan, 2013). Other groups achieved similar results against EAE-mediated damage in vivo through treatment with CNTF and CNTF-overexpressing mesenchymal stem cells (Kuhlmann et al., 2006; Lu et al., 2009). Neurogenesis during ischemic stroke is also enhanced by high levels of endogenous CNTF. According to Kang et al., CNTF upregulation during stroke, which is partially facilitated by $\mathrm{P} 2 \mathrm{X} 7$ receptor stimulation, increased numbers of immature neurons in the SVZ. This positive effect on neurogenesis was not observed in CNTF knockout mice (Kang, Keasey, Arnold, et al., 2013; Kang, Keasey, \& Hagg, 2013).

CNTF has been investigated as a therapeutic in preclinical studies for Huntington's disease, where it was shown to enhance survival of striatal neurons (Bachoud-Lévi et al., 2000; Emerich, Bruhn, Chu, \& Kordower, 1998; Mittoux et al., 2000). According to Colin et al., Akt signaling is decreased in human as well as animal models of Huntington's disease (Colin et al., 2005). Therefore, the activation of Akt signaling by CNTF could confer neuroprotection against striatal neurons in these models.

Moreover, the absence of CNTF expression has been shown to worsen the pathogenesis of EAE-induced demyelination (D'Souza, 1996). Compared to WT C57BL/6 mice, the CNTF knockout mice showed earlier symptoms of EAE, a greater incidence of relapse, and greater motor skill deficits (Linker et al., 2002) The severity of EAE symptoms among these 
knockout mice shows how cytokines acting through LIFR can ameliorate demyelination associated with EAE. Furthermore, CNTF has been shown to enhance remyelination by promoting the migration of NSCs toward active lesions where demyelination is occurring(Vernerey, Macchi, Magalon, Cayre, \& Durbec, 2013).

\section{Modulation of neuroinflammation through LIFR signaling}

\subsection{LIFR signaling controls phenotype of macrophages/microglia}

In addition to its pro-survival effects on neurons and oligodendrocytes, LIFR signaling may also indirectly contribute to neuroprotection/glioprotection after CNS injury through modulation of immune cell signaling. Although LIF is generally considered an antiinflammatory cytokine, there are several studies showing that LIFR signaling promotes inflammation after injury. For instance, CNTF-mediated activation of LIFR in murine macrophages caused the release of prostaglandin E2 and activated cyclooxygenase 2 (Cox-2). This effect was not inhibited upon administration of gp130 antibodies, thus indicating that LIFR-mediated activation of microglia is dependent upon LIFR and/or CNTFR signaling (Lin, Jain, Li, \& Levison, 2009). The overexpression of CNTF was also shown to exacerbate astroglial activation and neuronal degeneration in mouse models of CNS injury (Winter, Saotome, Levison, \& Hirsh, 1995; Winter, Saotome, Saotome, \& Hirsh, 1996).

Kerr and Patterson demonstrated that overexpression of LIF in the spinal cord promotes activation of microglia/macrophages during spinal cord injury, which contributes to neurodegeneration (Kerr \& Patterson, 2004). LIFR signaling also promotes chemotaxis of macrophages following mechanical injury to the cortex and sciatic nerve. In this study, LIF knockout mice showed significantly attenuated microglial and astroglial activation and increased macrophage infiltration after injury compared to wildtype mice (Sugiura et al., 2000). LIF knockout mice also showed a decrease in microglial activation after pilocarpineinduced injury (Holmberg \& Patterson, 2006) as well as less severe demyelination following induction of EAE (Linker et al., 2008).

However, Patterson and Kerr observed the opposite effect when they administered LIF systemically after spinal cord injury. According to the results of this study, systemic LIF injection promoted the release of insulin growth factor- 1 and other neurotrophic factors through activation of LIFR/Mac1 + microglia (Kerr \& Patterson, 2004). Peripheral macrophages have also been shown to switch from a pro-inflammatory to an antiinflammatory phenotype via LIFR activation. Monocytes treated with ovarian cancer ascites fluid differentiated into IL- $10^{\text {hlgh }}$ IL-12 $2^{\text {low }}$ tumor-associated macrophages. Removal of LIF and IL-6 from the ascites abolished this effect, thus demonstrating that LIFR signaling promotes the development of anti-inflammatory macrophages in the tumor microenvironment (Duluc et al., 2007; Jeannin, Duluc, \& Delneste, 2011). Macrophages also upregulate LIFR in response to stimulation with inflammatory mediators. For instance, stimulation with LPS (15 and $100 \mathrm{ng} / \mathrm{ml}$ ) significantly increased expression of LIFR on cultured macrophages. In this same study, macrophages treated with LIF in vitro developed phagocytic, anti-inflammatory phenotype. LIF administration lowered reactive oxygen species production, decreased TNF- $a$, and increased myelin uptake. Considering that 
oxidative stress and TNF- $a$ are major contributing factors to white matter damage during multiple sclerosis, $\mathrm{LIFR}^{+}$macrophages could enhance oligodendrocyte survival (Hendriks et al., 2008). A recent study by Goodus et al. demonstrates the paradoxical effect of LIF signaling on microglial and astroglial activation after concussive brain injury. In this study, mice that were heterozygotes for the LIF knockout showed decreased microglial activation after injury, but ultimately had worse functional outcomes and increased white matter damage (Goodus et al., 2016). These data show that the microglial phenotype induced by LIFR signaling appears to depend upon the synergistic effects of cytokines as well as the time-dependent change in the immune response after the injury. LIFR favors Treg over Th17 development.

Studies utilizing the EAE model demonstrate that the protective actions of LIFR signaling may not just be limited to the actions of LIF on white matter. For instance, Gresle et al. published a study demonstrating that LIF and CNTF protect against EAE injury in mice lacking gp130 expression in oligodendrocytes. These results demonstrate that LIF confers protection during EAE independently of its pro-survival signaling in oligodendrocytes (Gresle et al., 2012). $\mathrm{CD} 4{ }^{+} \mathrm{CD} 25^{+} \mathrm{FOXP}^{+}$regulatory $\mathrm{T}$ lymphocytes (Tregs) are responsible for inhibiting the $\mathrm{T}$ cell mediated inflammatory response. Patients with autoimmune diseases, such as multiple sclerosis, often have defects in Treg function and development (Viglietta, Baecher-Allan, Weiner, \& Hafler, 2004). Levy et al. (2015) showed that peripheral blood mononuclear cells (PBMCs) isolated from patients with relapsingremitting multiple sclerosis produced lower levels of LIF when stimulated with anti-CD3/ CD28 antibodies compared to the PBMCs from healthy control patients. These results suggest that defective production of LIF by T lymphocytes contributes to demyelination during MS (Levy et al., 2015).

During the maturation of naive $\mathrm{CD}^{+}{ }^{+} \mathrm{CD} 4^{+}$helper $\mathrm{T}$ lymphocytes, $\mathrm{LIF}$ treatment inhibits the development of CD4 + IL-17 + helper T (Th17) lymphocytes while favoring Treg development (Gao et al., 2009; Janssens et al., 2015). By contrast, IL-6 signaling promotes the development of Th17 lymphocytes and inhibits Treg development (Cao et al., 2011). Since IL-6 and LIF confer signaling through the gp130 receptor subunit the antiinflammatory developmental effects appear to be specific to LIFR signaling. Considering that Th17 lymphocytes contribute to neuroinflammation in conditions such as MS (JadidiNiaragh \& Mirshafiey, 2011) and ischemic stroke (Luo et al., 2015), LIFR signaling reduces $\mathrm{T}$ lymphocyte-mediated inflammation by controlling the development of helper $\mathrm{T}$ lymphocytes.

\section{Conclusion}

Considering the crucial role that LIFR plays in the pro-survival and anti-inflammatory effects of IL-6 cytokines, increasing its activity and expression should promote tissue repair and better outcomes in models of neurodegeneration and inflammation. Although several groups have evaluated IL-6 family cytokines such as LIF, CNTF, and CT-1 as therapeutics against neurodegenerative disease, LIFR activation is a common signaling mechanism for these neuroprotective cytokines (Fig. 1). In spite of signaling through a common receptor, LIFR-activating cytokines exert pleiotropic effects on several cell populations of the CNS 
(Fig. 2). Increasing the activity of LIFR through preventing its endocytosis, increasing protein expression, or promoting its association with gp130/CNTF should improve the efficacy of neurokine administration and increase the feasibility of this therapeutic strategy (Fig. 3).

\section{Acknowledgments}

Conflict of interest

The authors declare that there are no conflicts of interest.

Funding was provided by NINDSR01NS091146.

\section{Abbreviations:}

CT-1

CNTF

EAE

GPI

gp130

JAK

LIF

LBP

NSC

OPC

OSM

PBMC

Tregs cardiotrophin-1

ciliary neurotrophic factor

experimental allergic encephalomyelitis

glycosyl-phosphatidylinositol

high-affinity-converting glycoprotein 130

Janus kinase

leukemia inhibitory factor

LIF-binding protein

neural stem cell

oligodendrocyte progenitor cell

oncostatin M

peripheral blood mononuclear cell

regulatory $\mathrm{T}$ lymphocytes

\section{References}

Ajmo CT, Jr., Vernon DO, Collier L, Hall AA, Garbuzova-Davis S, Willing A, \& Pennypacker KR (2008). The spleen contributes to stroke-induced neurodegeneration. Journal of Neuroscience Research, 86, 2227-2234. [PubMed: 18381759]

Albrecht PJ, Dahl JP, Stoltzfus OK, Levenson R, \& Levison SW (2002). Ciliary neurotrophic factor activates spinal cord astrocytes, stimulating their production and release of fibroblast growth factor-2, to increase motor neuron survival. Experimental Neurology, 173, 46-62. [PubMed: 11771938]

Argetsinger LS, Hsu GW, Myers MG, Jr., Billestrup N, White MF, \& Carter-Su C (1995). Growth hormone, interferon-gamma, and leukemia inhibitory factor promoted tyrosyl phosphorylation of insulin receptor substrate-1. The Journal of Biological Chemistry, 270, 14685-14692. [PubMed: 7782332] 
Azari MF, Galle A, Lopes EC, Kurek J, \& Cheema SS (2001). Leukemia inhibitory factor by systemic administration rescues spinal motor neurons in the SOD1 G93A murine model of familial amyotrophic lateral sclerosis. Brain Research, 922, 144-147. [PubMed: 11730713]

Azari MF, Lopes EC, Stubna C, Turner BJ, Zang D, Nicola NA, ... Cheema SS (2003). Behavioural and anatomical effects of systemically administered leukemia inhibitory factor in the SOD1 G93A G1H mouse model of familial amyotrophic lateral sclerosis. Brain Research, 982, 92-97. [PubMed: 12915243]

Azari MF, Profyris C, Karnezis T, Bernard CC, Small DH, Cheema SS, ... Petratos S (2006). Leukemia inhibitory factor arrests oligodendrocyte death and demyelination in spinal cord injury. Journal of Neuropathology and Experimental Neurology, 65, 914-929. [PubMed: 16957585]

Bachoud-Lévi A-C, Deglon N, Nguyen J-P, Bloch J, Bourdet C, Winkel L, ... Brugieres P (2000). Neuroprotective gene therapy for Huntington's disease using a polymer encapsulated BHK cell line engineered to secrete human CNTF. Human Gene Therapy, 11, 1723-1729. [PubMed: 10954906]

Banner LR, Moayeri NN, \& Patterson PH (1997). Leukemia inhibitory factor is expressed in astrocytes following cortical brain injury. Experimental Neurology, 147, 1-9. [PubMed: 9294397]

Barnabé-Heider F, Wasylnka JA, Fernandes KJL, Porsche C, Sendtner M, Kaplan DR, \& Miller FD (2005). Evidence that embryonic neurons regulate the onset of cortical gliogenesis via cardiotrophin-1. Neuron, 48, 253-265. [PubMed: 16242406]

Bauer S, Kerr BJ, \& Patterson PH (2007). The neuropoietic cytokine family in development, plasticity, disease and injury. Nature Reviews. Neuroscience, 8, 221-232. [PubMed: 17311007]

Bauer S, \& Patterson PH (2006). Leukemia inhibitory factor promotes neural stem cell self-renewal in the adult brain. The Journal of Neuroscience, 26, 12089-12099. [PubMed: 17108182]

Binetruy B, Heasley L, Bost F, Caron L, \& Aouadi M (2007). Concise review: Regulation of embryonic stem cell lineage commitment by mitogen-activated protein kinases. Stem Cells, 25, 1090-1095. [PubMed: 17218395]

Blanchard F, Duplomb L, Wang Y, Robledo O, Kinzie E, Pitard V, ... Baumann H (2000). Stimulation of leukemia inhibitory factor receptor degradation by extracellular signal-regulated kinase. The Journal of Biological Chemistry, 275, 28793-28801. [PubMed: 10858440]

Bonni A, Sun Y, Nadal-Vicens M, Bhatt A, Frank D, Rozovsky I, ... Greenberg M (1997). Regulation of gliogenesis in the central nervous system by the JAK-STAT signaling pathway. Science, 278, 477-483. [PubMed: 9334309]

Boulton TG, Stahl N, \& Yancopoulos GD (1994). Ciliary neurotrophic factor/leukemia inhibitory factor/interleukin 6/oncostatin M family of cytokines induces tyrosine phosphorylation of a common set of proteins overlapping those induced by other cytokines and growth factors. The Journal of Biological Chemistry, 269, 11648-11655. [PubMed: 7512571]

Bugga L, Gadient RA, Kwan K, Stewart CL, \& Patterson PH (1998). Analysis of neuronal and glial phenotypes in brains of mice deficient in leukemia inhibitory factor. Journal of Neurobiology, 36, 509-524. [PubMed: 9740023]

Buono KD, Vadlamuri D, Gan Q, \& Levison SW (2012). Leukemia inhibitory factor is essential for subventricular zone neural stem cell and progenitor homeostasis as revealed by a novel flow cytometric analysis. Developmental Neuroscience, 34, 449-462. [PubMed: 23258129]

Butzkueven H, Emery B, Cipriani T, Marriott MP, \& Kilpatrick TJ (2006). Endogenous leukemia inhibitory factor production limits autoimmune demyelination and oligodendrocyte loss. Glia, 53, 696-703. [PubMed: 16498619]

Butzkueven H, Zhang JG, Soilu-Hanninen M, Hochrein H, Chionh F, Shipham KA, ... Kilpatrick TJ (2002). LIF receptor signaling limits immune-mediated demyelination by enhancing oligodendrocyte survival. Nature Medicine, 8, 613-619.

Cao W, Yang Y, Wang Z, Liu A, Fang L, Wu F, ... Zhang JZ (2011). Leukemia inhibitory factor inhibits $T$ helper 17 cell differentiation and confers treatment effects of neural progenitor cell therapy in autoimmune disease. Immunity, 35, 273-284. [PubMed: 21835648]

Chen CW, Okada M, Proto JD, Gao X, Sekiya N, Beckman SA, ... Huard J (2013). Human pericytes for ischemic heart repair. Stem Cells, 31, 305-316. [PubMed: 23165704] 
Chojnacki A, Shimazaki T, Gregg C, Weinmaster G, \& Weiss S (2003). Glycoprotein 130 signaling regulates Notch1 expression and activation in the self-renewal of mammalian forebrain neural stem cells. The Journal of Neuroscience, 23, 1730-1741. [PubMed: 12629177]

Chun LL, \& Patterson PH (1977). Role of nerve growth factor in the development of rat sympathetic neurons in vitro. III. Effect on acetylcholine production. The Journal of Cell Biology, 75, 712-718. [PubMed: 925077]

Colin E, Régulier E, Perrin V, Dürr A, Brice A, Aebischer P, ... Saudou F (2005). Akt is altered in an animal model of Huntington's disease and in patients. The European Journal of Neuroscience, 21, 1478-1488. [PubMed: 15845076]

Covey MV, \& Levison SW (2007). Leukemia inhibitory factor participates in the expansion of neural stem/progenitors after perinatal hypoxia/ischemia. Neuroscience, 148, 501-509. [PubMed: 17664044]

Davis S, Aldrich TH, Valenzuela DM, Wong V, Furth ME, Squinto SP, \& Yancopoulos GD (1991). The receptor for ciliary neurotrophic factor. Science, 253, 59-63. [PubMed: 1648265]

Davis SM, Collier LA, Leonardo CC, Seifert HA, Ajmo CT, Jr., \& Pennypacker KR (2016). Leukemia inhibitory factor protects neurons from ischemic damage via upregulation of superoxide dismutase 3. Molecular Neurobiology, 54(1), 608-622. [PubMed: 26746670]

DeChiara TM, Vejsada R, Poueymirou WT, Acheson A, Suri C, Conover JC, ... Yancopoulos GD (1995). Mice lacking the CNTF receptor, unlike mice lacking CNTF, exhibit profound motor neuron deficits at birth. Cell, 83, 313-322. [PubMed: 7585948]

Deverman BE, \& Patterson PH (2012). Exogenous leukemia inhibitory factor stimulates oligodendrocyte progenitor cell proliferation and enhances hippocampal remyelination. The Journal of Neuroscience, 32, 2100-2109. [PubMed: 22323722]

D'Souza SD (1996). Response of human oligodendrocytes to immune-mediated injury: Selective vulnerability and selective protection. Montreal: McGill University.

Duluc D, Delneste Y, Tan F, Moles MP, Grimaud L, Lenoir J, ... Jeannin P (2007). Tumor-associated leukemia inhibitory factor and IL-6 skew monocyte differentiation into tumor-associated macrophage-like cells. Blood, 110, 4319-4330. [PubMed: 17848619]

Dyson S, Fahmy T, Metcalfe S, \& Barker R (2014). Evaluation of PLGA nanoparticles carrying leukaemia inhibitory factor for stromal-like support of rat fetal dopaminergic Cells. Journal of Nanomaterials \& Molecular Nanotechnology, S2 (003. of, 6, 2).

Emerich D, Bruhn S, Chu Y, \& Kordower J (1998). Cellular delivery of CNTF but not NT-4/5 prevents degeneration of striatal neurons in a rodent model of Huntington's disease. Cell Transplantation, 7, 213-225. [PubMed: 9588602]

Emsley J, \& Hagg T (2003). Endogenous and exogenous ciliary neurotrophic factor enhances forebrain neurogenesis in adult mice. Experimental Neurology, 183, 298-310. [PubMed: 14552871]

Engelhardt M, di Cristo G, Grabert J, Patz S, Maffei L, Berardi N, \& Wahle P (2017). Leukemia inhibitory factor impairs structural and neurochemical development of rat visual cortex in vivo. Molecular and Cellular Neuroscience, 79, 81-92. [PubMed: 28088609]

Fan G, \& Katz DM (1993). Non-neuronal cells inhibit catecholaminergic differentiation of primary sensory neurons: Role of leukemia inhibitory factor. Development, 118, 83-93. [PubMed: 8104145]

Felling RJ, Covey MV, Wolujewicz P, Batish M, \& Levison SW (2016). Astrocyte-produced leukemia inhibitory factor expands the neural stem/progenitor pool following perinatal hypoxia-ischemia. Journal of Neuroscience Research, 94, 1531-1545. [PubMed: 27661001]

Fischer R, Wajant H, Kontermann R, Pfizenmaier K, \& Maier O (2014). Astrocyte-specific activation of TNFR2 promotes oligodendrocyte maturation by secretion of leukemia inhibitory factor. Glia, 62, 272-283. [PubMed: 24310780]

Gadina M, Hilton D, Johnston JA, Morinobu A, Lighvani A, Zhou YJ, ... O’Shea JJ (2001). Signaling by type I and II cytokine receptors: Ten years after. Current Opinion in Immunology, 13, 363-373. [PubMed: 11406370]

Galli R, Pagano SF, Gritti A, \& Vescovi AL (2000). Regulation of neuronal differentiation in human CNS stem cell progeny by leukemia inhibitory factor. Developmental Neuroscience, 22, 86-95. [PubMed: 10657701] 
Gao W, Thompson L, Zhou Q, Putheti P, Fahmy TM, Strom TB, \& Metcalfe SM (2009). Treg versus Th17 lymphocyte lineages are cross-regulated by LIF versus IL-6. Cell Cycle, 8, 1444-1450. [PubMed: 19342884]

Gard AL, Burrell MR, Pfeiffer SE, Rudge JS, \& Williams WC, II (1995). Astroglial control of oligodendrocyte survival mediated by PDGF and leukemia inhibitory factor-like protein. Development, 121, 2187-2197. [PubMed: 7635062]

Gardiner NJ, Cafferty WBJ, Slack SE, \& Thompson SWN (2002). Expression of gp130 and leukaemia inhibitory factor receptor subunits in adult rat sensory neurones: regulation by nerve injury. Journal of Neurochemistry, 83, 100-109. [PubMed: 12358733]

Gearing DP, Comeau MR, Friend DJ, Gimpel SD, Thut CJ, McGourty J, ... Mosley B (1992). The IL-6 signal transducer, gp130: an oncostatin M receptor and affinity converter for the LIF receptor. Science, 255, 1434-1437. [PubMed: 1542794]

Gearing D, Thut C, VandeBos T, Gimpel S, Delaney P, King J, ... Beckmann M (1991). Leukemia inhibitory factor receptor is structurally related to the IL-6 signal transducer, gp130. The EMBO Journal, 10, 2839. [PubMed: 1915266]

Getchell TV, Shah DS, Partin JV, Subhedar NK, \& Getchell ML (2002). Leukemia inhibitory factor mRNA expression is upregulated in macrophages and olfactory receptor neurons after target ablation. Journal of Neuroscience Research, 67, 246-254. [PubMed: 11782968]

Goodus MT, Kerr NA, Talwar R, Buziashvili D, Fragale JE, Pang KC, \& Levison SW (2016). Leukemia inhibitory factor haplodeficiency desynchronizes glial reactivity and exacerbates damage and functional deficits after a concussive brain injury. Journal of Neurotrauma, 33, 15221534. [PubMed: 26541248]

Graf U, Casanova EA, \& Cinelli P (2011). The role of the leukemia inhibitory factor (LIF) - Pathway in derivation and maintenance of murine pluripotent stem cells. Genes, 2, 280-297. [PubMed: 24710148]

Gresle MM, Alexandrou E, Wu Q, Egan G, Jokubaitis V, Ayers M, ... Butzkueven H (2012). Leukemia inhibitory factor protects axons in experimental autoimmune encephalomyelitis via an oligodendrocyte-independent mechanism. PloS One, 7, e47379. [PubMed: 23077604]

Hagg T (2005). Molecular regulation of adult CNS neurogenesis: An integrated view. Trends in Neurosciences, 28, 589-595. [PubMed: 16153715]

Hendriks JJ, Slaets H, Carmans S, de Vries HE, Dijkstra CD, Stinissen P, \& Hellings N (2008). Leukemia inhibitory factor modulates production of inflammatory mediators and myelin phagocytosis by macrophages. Journal of Neuroimmunology, 204, 52-57. [PubMed: 18771807]

Holmberg KH, \& Patterson PH (2006). Leukemia inhibitory factor is a key regulator of astrocytic, microglial and neuronal responses in a low-dose pilocarpine injury model. Brain Research, 1075, 26-35. [PubMed: 16458863]

Ip NY, McClain J, Barrezueta NX, Aldrich TH, Pan L, Li Y, ... Yancopoulos GD (1993). The a component of the CNTF receptor is required for signaling and defines potential CNTF targets in the adult and during development. Neuron, 10, 89-102. [PubMed: 8381290]

Ip NY, Nye SH, Boulton TG, Davis SM, Taga T, Li Y, ... Yancopoulos GD (1992). CNTF and LIF act on neuronal cells via shared signaling pathways that involve the IL-6 signal transducing receptor component gp130. Cell, 69, 1121-1132. [PubMed: 1617725]

Ishibashi T, Lee PR, Baba H, \& Fields RD (2009). Leukemia inhibitory factor regulates the timing of oligodendrocyte development and myelination in the postnatal optic nerve. Journal of Neuroscience Research, 87, 3343-3355. [PubMed: 19598242]

Jadidi-Niaragh F, \& Mirshafiey A (2011). Th17 cell, the new player of neuroinflammatory process in multiple sclerosis. Scandinavian Journal of Immunology, 74, 1-13. [PubMed: 21338381]

Janssens K, Van den Haute C, Baekelandt V, Lucas S, van Horssen J, Somers V, ... Hellings N (2015). Leukemia inhibitory factor tips the immune balance towards regulatory $\mathrm{T}$ cells in multiple sclerosis. Brain, Behavior, and Immunity, 45, 180-188.

Jeannin P, Duluc D, \& Delneste Y (2011). IL-6 and leukemia-inhibitory factor are involved in the generation of tumor-associated macrophage: regulation by IFN-gamma. Immunotherapy, 3, 23-26. 
Johnson JA, \& Nathanson NM (1994). Differential requirements for p21ras and protein kinase C in the regulation of neuronal gene expression by nerve growth factor and neurokines. Journal of Biological Chemistry, 269, 18856-18863. [PubMed: 8034640]

Kang SS, Keasey MP, Arnold SA, Reid R, Geralds J, \& Hagg T (2013). Endogenous CNTF mediates stroke-induced adult CNS neurogenesis in mice. Neurobiology of Disease, 49, 68-78. [PubMed: 22960105]

Kang SS, Keasey MP, \& Hagg T (2013). P2X7 receptor inhibition increases CNTF in the subventricular zone, but not neurogenesis or neuroprotection after stroke in adult mice. Translational Stroke Research, 4, 533-545. [PubMed: 24312160]

Kerr BJ, \& Patterson PH (2004). Potent pro-inflammatory actions of leukemia inhibitory factor in the spinal cord of the adult mouse. Experimental Neurology, 188, 391-407. [PubMed: 15246839]

Koblar SA, Turnley AM, Classon BJ, Reid KL, Ware CB, Cheema SS, ... Bartlett PF (1998). Neural precursor differentiation into astrocytes requires signaling through the leukemia inhibitory factor receptor. Proceedings of the National Academy of Sciences of the United States of America, 95, 3178-3181. [PubMed: 9501236]

Kuhlmann T, Remington L, Cognet I, Bourbonniere L, Zehntner S, Guilhot F, ... Owens T (2006). Continued administration of ciliary neurotrophic factor protects mice from inflammatory pathology in experimental autoimmune encephalomyelitis. The American Journal of Pathology, 169, 584-598. [PubMed: 16877358]

Laterza C, Merlini A, De Feo D, Ruffini F, Menon R, Onorati M, ... Martino G (2013). iPSC-derived neural precursors exert a neuroprotective role in immune-mediated demyelination via the secretion of LIF. Nature Communications, 4, 2597.

Layton M, Cross B, Metcalf D, Ward L, Simpson R, \& Nicola N (1992). A major binding protein for leukemia inhibitory factor in normal mouse serum: Identification as a soluble form of the cellular receptor. Proceedings of the National Academy of Sciences of the United States of America, 89, 8616-8620. [PubMed: 1528870]

Levy YA, Mausner-Fainberg K, Vaknin-Dembinsky A, Amidror T, Regev K, \& Karni A (2015). Dysregulated production of leukemia inhibitory factor in immune cells of relapsing remitting multiple sclerosis patients. Journal of Neuroimmunology, 278, 85-89. [PubMed: 25595256]

Lewis SE, Rao MS, Symes AJ, Dauer WT, Fink JS, Landis SC, \& Hyman SE (1994). Coordinate regulation of choline acetyltransferase, tyrosine hydroxylase, and neuropeptide mRNAs by ciliary neurotrophic factor and leukemia inhibitory factor in cultured sympathetic neurons. Journal of Neurochemistry, 63, 429-438. [PubMed: 7518494]

Li M, Sendtner M, \& Smith A (1995). Essential function of LIF receptor in motor neurons. Nature, 378, 724-727. [PubMed: 7501019]

Lin H-W, Jain MR, Li H, \& Levison SW (2009). Ciliary neurotrophic factor (CNTF) plus soluble CNTF receptor $a$ increases cyclooxygenase- 2 expression, PGE2release and interferon- $\gamma$-induced CD40 in murine microglia. Journal of Neuroinflammation, 6, 7. [PubMed: 19267906]

Lindberg R, Juan T, Welcher A, Sun Y, Cupples R, Guthrie B, \& Fletcher F (1998). Cloning and characterization of a specific receptor for mouse oncostatin M. Molecular and Cellular Biology, 18, 3357-3367. [PubMed: 9584176]

Linker RA, Kruse N, Israel S, Wei T, Seubert S, Hombach A, ... Gold R (2008). Leukemia inhibitory factor deficiency modulates the immune response and limits autoimmune demyelination: A new role for neurotrophic cytokines in neuroinflammation. Journal of Immunology, 180, 2204-2213.

Linker RA, Maurer M, Gaupp S, Martini R, Holtmann B, Giess R, ... Gold R (2002). CNTF is a major protective factor in demyelinating CNS disease: A neurotrophic cytokine as modulator in neuroinflammation. Nature Medicine, 8, 620-624.

Lu Z, Hu X, Zhu C, Wang D, Zheng X, \& Liu Q (2009). Overexpression of CNTF in mesenchymal stem cells reduces demyelination and induces clinical recovery in experimental autoimmune encephalomyelitis mice. Journal of Neuroimmunology, 206, 58-69. [PubMed: 19081144]

Luo Y, Zhou Y, Xiao W, Liang Z, Dai J, Weng X, \& Wu X (2015). Interleukin-33 ameliorates ischemic brain injury in experimental stroke through promoting Th2 response and suppressing Th17 response. Brain Research, 1597, 86-94. [PubMed: 25500143] 
Majumder A, Banerjee S, Harrill JA, Machacek DW, Mohamad O, Bacanamwo M, ... Stice SL (2012). Neurotrophic effects of leukemia inhibitory factor on neural cells derived from human embryonic stem cells. Stem Cells, 30, 2387-2399. [PubMed: 22899336]

Mayer M, Bhakoo K, \& Noble M (1994). Ciliary neurotrophic factor and leukemia inhibitory factor promote the generation, maturation and survival of oligodendrocytes in vitro. Development, 120, 143-153. [PubMed: 8119123]

Mi H, Haeberle H, \& Barres BA (2001). Induction of astrocyte differentiation by endothelial cells. The Journal of Neuroscience, 21, 1538-1547. [PubMed: 11222644]

Mittoux V, Joseph J, Conde F, Palfi S, Dautry C, Poyot T, ... Nimchinsky E (2000). Restoration of cognitive and motor functions by ciliary neurotrophic factor in a primate model of Huntington's disease. Human Gene Therapy, 11, 1177-1188. [PubMed: 10834619]

Miyajima A, Kinoshita T, Tanaka M, Kamiya A, Mukouyama Y, \& Hara T (2000). Role of oncostatin $\mathrm{M}$ in hematopoiesis and liver development. Cytokine \& Growth Factor Reviews, 11, 177-183.

Modi KK, Sendtner M, \& Pahan K (2013). Up-regulation of ciliary neurotrophic factor in astrocytes by aspirin implications for remyelination in multiple sclerosis. Journal of Biological Chemistry, 288, 18533-18545. [PubMed: 23653362]

Moidunny S, Vinet J, Wesseling E, Bijzet J, Shieh CH, van Ijzendoorn SC, ... Biber K (2012). Adenosine A (2B) receptor-mediated leukemia inhibitory factor release from astrocytes protects cortical neurons against excitotoxicity. Journal of Neuroinflammation, 9, 198. [PubMed: 22894638]

Moon C, Yoo J, Matarazzo V, Sung Y, Kim E, \& Ronnett G (2002). Leukemia inhibitory factor inhibits neuronal terminal differentiation through STAT3 activation. Proceedings of the National Academy of Sciences of the United States of America, 99, 9015-9020. [PubMed: 12084939]

Müller S, Chakrapani BPS, Schwegler H, Hofmann H-D, \& Kirsch M (2009). Neurogenesis in the dentate gyrus depends on ciliary neurotrophic factor and signal transducer and activator of transcription 3 signaling. Stem Cells, 27, 431-441. [PubMed: 19023034]

Murphy M, Reid K, Hilton DJ, \& Bartlett PF (1991). Generation of sensory neurons is stimulated by leukemia inhibitory factor. Proceedings of the National Academy of Sciences, 88, 3498-3501.

Nakashima K, Yanagisawa M, Arakawa H, \& Taga T (1999). Astrocyte differentiation mediated by LIF in cooperation with BMP2. FEBS Letters, 457, 43-46. [PubMed: 10486560]

Offner H, Subramanian S, Parker SM, Afentoulis ME, Vandenbark AA, \& Hurn PD (2006). Experimental stroke induces massive, rapid activation of the peripheral immune system. Journal of Cerebral Blood Flow and Metabolism, 26, 654-665. [PubMed: 16121126]

Oh H, Fujio Y, Kunisada K, Hirota H, Matsui H, Kishimoto T, \& Yamauchi-Takihara K (1998). Activation of phosphatidylinositol 3-kinase through glycoprotein 130 induces protein kinase B and p70 S6 kinase phosphorylation in cardiac myocytes. The Journal of Biological Chemistry, 273, 9703-9710. [PubMed: 9545305]

Ott V, Fasshauer M, Meier B, Dalski A, Kraus D, Gettys TW, ... Klein J (2004). Ciliary neurotrophic factor influences endocrine adipocyte function: Inhibition of leptin via PI 3-kinase. Molecular and Cellular Endocrinology, 224, 21-27. [PubMed: 15353177]

Owczarek CM, Layton MJ, Robb LG, Nicola NA, \& Begley CG (1996). Molecular basis of the soluble and membrane-bound forms of the murine leukemia inhibitory factor receptor-chain expression in normal, gestating, and leukemia inhibitory factor nullizygous mice. Journal of Biological Chemistry, 271, 5495-5504. [PubMed: 8621407]

Pasquin S, Sharma M, \& Gauchat J-F (2015). Ciliary neurotrophic factor (CNTF): New facets of an old molecule for treating neurodegenerative and metabolic syndrome pathologies. Cytokine \& Growth Factor Reviews, 26, 507-515. [PubMed: 26187860]

Pitman M, Emery B, Binder M, Wang S, Butzkueven H, \& Kilpatrick T (2004). LIF receptor signaling modulates neural stem cell renewal. Molecular and Cellular Neurosciences, 27, 255-266. [PubMed: 15519241]

Port MD, Gibson RM, \& Nathanson NM (2007). Differential stimulation-induced receptor localization in lipid rafts for interleukin- 6 family cytokines signaling through the gp130/leukemia inhibitory factor receptor complex. Journal of Neurochemistry, 101, 782-793. [PubMed: 17448148] 
Richards LJ, Kilpatrick TJ, Bartlett PF, \& Murphy M (1992). Leukemia inhibitory factor promotes the neuronal development of spinal cord precursors from the neural tube. Journal of Neuroscience Research, 33, 476-484. [PubMed: 1469749]

Richards LJ, Kilpatrick TJ, Dutton R, Tan SS, Gearing DP, Bartlett PF, \& Murphy M (1996). Leukaemia inhibitory factor or related factors promote the differentiation of neuronal and astrocytic precursors within the developing murine spinal cord. The European Journal of Neuroscience, 8, 291-299. [PubMed: 8714700]

Rittchen S, Boyd A, Burns A, Park J, Fahmy TM, Metcalfe S, \& Williams A (2015). Myelin repair in vivo is increased by targeting oligodendrocyte precursor cells with nanoparticles encapsulating leukaemia inhibitory factor (LIF). Biomaterials, 56, 78-85. [PubMed: 25934281]

Robledo O, Fourcin M, Chevalier S, Guillet C, Auguste P, Pouplard-Barthelaix A, ... Gascan H (1997). Signaling of the cardiotrophin-1 receptor: Evidence for a third receptor component. Journal of Biological Chemistry, 272, 4855-4863. [PubMed: 9030543]

Rowe DD, Collier LA, Seifert HA, Chapman CB, Leonardo CC, Willing AE, \& Pennypacker KR (2014). Leukemia inhibitory factor promotes functional recovery and oligodendrocyte survival in rat models of focal ischemia. The European Journal of Neuroscience, 40, 3111-3119. [PubMed: 25041106]

Rowe DD, Leonardo CC, Recio JA, Collier LA, Willing AE, \& Pennypacker KR (2012). Human umbilical cord blood cells protect oligodendrocytes from brain ischemia through Akt signal transduction. The Journal of Biological Chemistry, 287, 4177-4187. [PubMed: 22158864]

Schiemann WP, Graves LM, Baumann H, Morella KK, Gearing DP, Nielsen MD, ... Nathanson NM (1995). Phosphorylation of the human leukemia inhibitory factor (LIF) receptor by mitogenactivated protein kinase and the regulation of LIF receptor function by heterologous receptor activation. Proceedings of the National Academy of Sciences, 92, 5361-5365.

Shimazaki T, Shingo T, \& Weiss S (2001). The ciliary neurotrophic factor/leukemia inhibitory factor/ gp130 receptor complex operates in the maintenance of mammalian forebrain neural stem cells. The Journal of Neuroscience, 21, 7642-7653. [PubMed: 11567054]

Slaets H, Dumont D, Vanderlocht J, Noben JP, Leprince P, Robben J, ... Hellings N (2008). Leukemia inhibitory factor induces an antiapoptotic response in oligodendrocytes through Aktphosphorylation and up-regulation of 14-3-3. Proteomics, 8, 1237-1247. [PubMed: 18338825]

Stahl N, Boulton TG, Farruggella T, Ip NY, Davis S, Witthuhn BA, Quelle FW, Silvennoinen O, Barbieri G, Pellegrini S, et al. (1994). Association and activation of Jak-Tyk kinases by CNTFLIF-OSM-IL-6 beta receptor components. Science, 263, 92-95. [PubMed: 8272873]

Stahl N, Farruggella TJ, Boulton TG, Zhong Z, Darnell JE, Jr., \& Yancopoulos GD (1995). Choice of STATs and other substrates specified by modular tyrosine-based motifs in cytokine receptors. Science, 267, 1349-1353. [PubMed: 7871433]

Sugiura S, Lahav R, Han J, Kou SY, Banner LR, de Pablo F, \& Patterson PH (2000). Leukaemia inhibitory factor is required for normal inflammatory responses to injury in the peripheral and central nervous systems in vivo and is chemotactic for macrophages in vitro. The European Journal of Neuroscience, 12, 457-466. [PubMed: 10712626]

Suzuki S, Yamashita T, Tanaka K, Hattori H, Sawamoto K, Okano H, \& Suzuki N (2005). Activation of cytokine signaling through leukemia inhibitory factor receptor (LIFR)/gp130 attenuates ischemic brain injury in rats. Journal of Cerebral Blood Flow and Metabolism, 25, 685-693. [PubMed: 15716858]

Talbott J, Cao Q, Bertram J, Nkansah M, Benton R, Lavik E, \& Whittemore S (2007). CNTF promotes the survival and differentiation of adult spinal cord-derived oligodendrocyte precursor cells in vitro but fails to promote remyelination in vivo. Experimental Neurology, 204, 485-489. [PubMed: 17274982]

Tanaka M, Hara T, Copeland N, Gilbert D, Jenkins N, \& Miyajima A (1999). Reconstitution of the functional mouse oncostatin $\mathrm{M}$ (OSM) receptor: molecular cloning of the mouse OSM receptor beta subunit. Blood, 93, 804-815. [PubMed: 9920829]

Tomida M, Yamamoto-Yamaguchi Y, \& Hozumi M (1994). Three different cDNAs encoding mouse Dfactor/LIF receptor. Journal of Biochemistry, 115, 557-562. [PubMed: 8056772] 
Tripathi RB, \& Mctigue DM (2008). Chronically increased ciliary neurotrophic factor and fibroblast growth factor-2 expression after spinal contusion in rats. Journal of Comparative Neurology, 510, 129-144. [PubMed: 18615534]

Vernerey J, Macchi M, Magalon K, Cayre M, \& Durbec P (2013). Ciliary neurotrophic factor controls progenitor migration during remyelination in the adult rodent brain. Journal of Neuroscience, 33, 3240-3250. [PubMed: 23407977]

Viglietta V, Baecher-Allan C, Weiner HL, \& Hafler DA (2004). Loss of functional suppression by CD4+ CD25+ regulatory T cells in patients with multiple sclerosis. The Journal of Experimental Medicine, 199, 971-979. [PubMed: 15067033]

Ware CB, Horowitz MC, Renshaw BR, Hunt JS, Liggitt D, Koblar SA, Gliniak BC, McKenna HJ, Papayannopoulou T, Thoma B, et al. (1995). Targeted disruption of the low-affinity leukemia inhibitory factor receptor gene causes placental, skeletal, neural and metabolic defects and results in perinatal death. Development, 121, 1283-1299. [PubMed: 7789261]

Winter CG, Saotome Y, Levison SW, \& Hirsh D (1995). A role for ciliary neurotrophic factor as an inducer of reactive gliosis, the glial response to central nervous system injury. Proceedings of the National Academy of Sciences, 92, 5865-5869.

Winter CG, Saotome Y, Saotome I, \& Hirsh D (1996). CNTF overproduction hastens onset of symptoms in motor neuron degeneration (mnd) mice. Developmental Neurobiology, 31, 370378.

Wright LS, Li J, Caldwell MA, Wallace K, Johnson JA, \& Svendsen CN (2003). Gene expression in human neural stem cells: Effects of leukemia inhibitory factor. Journal of Neurochemistry, 86, 179-195. [PubMed: 12807438]

Yilmaz G, Arumugam TV, Stokes KY, \& Granger DN (2006). Role of T lymphocytes and interferongamma in ischemic stroke. Circulation, 113, 2105-2112. [PubMed: 16636173]

Yoshida T, Satoh M, Nakagaito Y, Kuno H, \& Takeuchi M (1993). Cytokines affecting survival and differentiation of an astrocyte progenitor cell line. Brain Research. Developmental Brain Research, 76, 147-150. [PubMed: 8306427] 


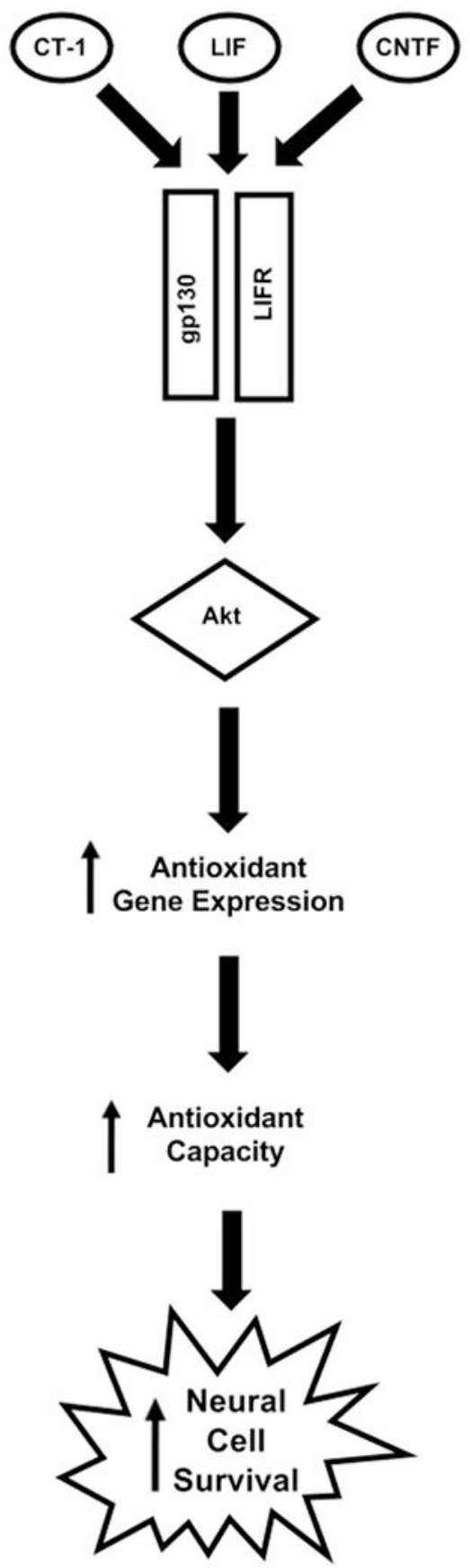

Fig. 1.

LIFR-activating cytokines increase survival during neurodegeneration.

By signaling through LIFR, the cytokines LIF, CNTF, and CT-1 increase Akt activity, which promotes the transcription of pro-survival genes. Several of these genes include antioxidant enzymes which protect cells of the CNS against reactive oxygen species generated by cytotoxicity and immune cell activation. These enzymes increase the antioxidant capacity of the brain and increase survival while decreasing tissue damage. 

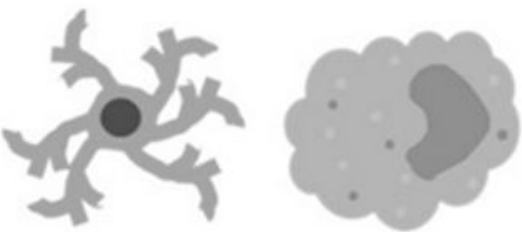

$-\uparrow$ IL-10 secretion (LIF)

] IL-12 secretion (LIF)

$-\uparrow$ Microglial activation (CNTF)

$-\uparrow$ Myelin phagocytosis (LIF)

$\downarrow$ ROS and TNFa production (LIF)

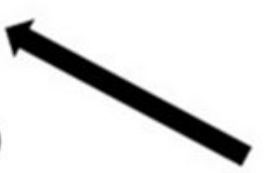

Th17 differentiation (LIF)

Treg differentiation (LIF)

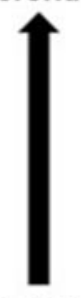

LIFR

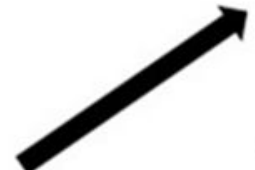
(CNTF)

\section{Activation}

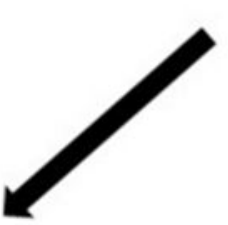

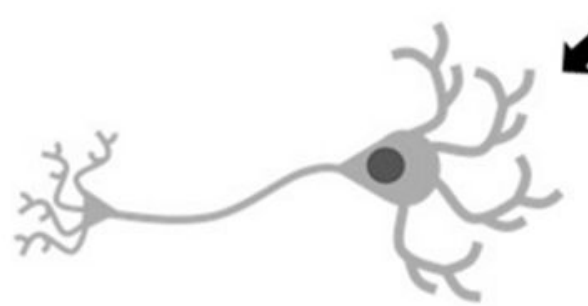

$\uparrow$ Neurogenesis (CNTF, LIF)

6 Neurogenesis in olfactory bulb (LIF)

$\uparrow$ Survival (CNTF, CT-1, LIF)

$\uparrow$ Antioxidant Expression (LIF, CNTF)

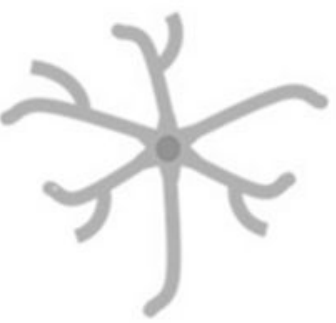

Astrogliogenesis (CNTF, CT-1, LIF)

\section{Fig. 2.}

The Pleiotropic Effects of LIFR activation on CNS Cell Populations.

Depending upon the cell type, LIFR signaling exerts wide-ranging and often conflicting effects on cellular survival, maintenance, and development. 


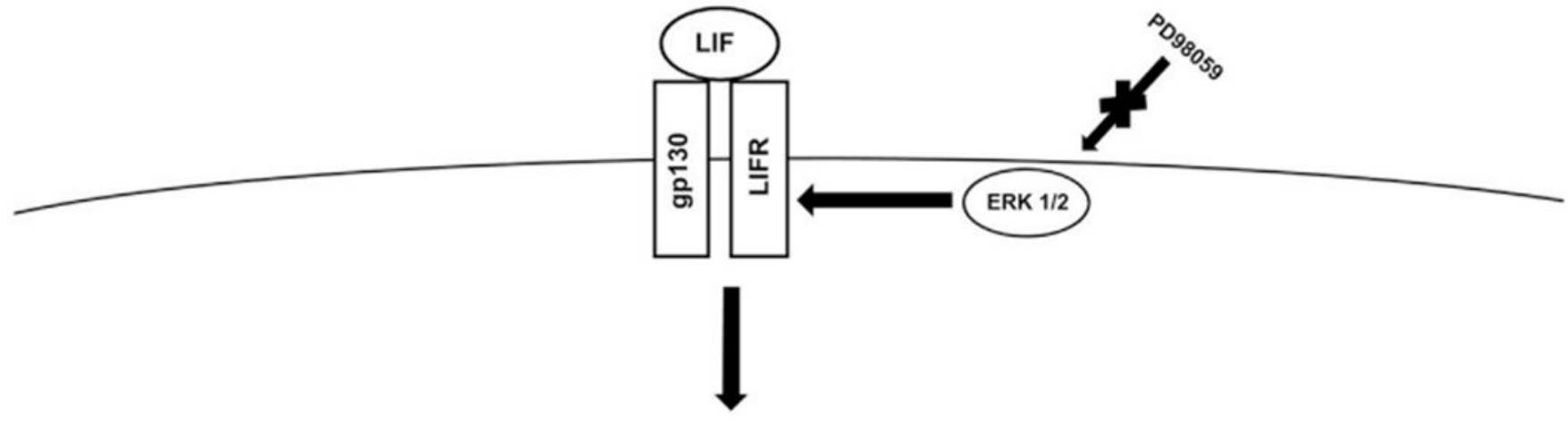

\section{Endocytosis}

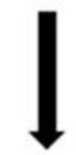

Lysosomal degradation

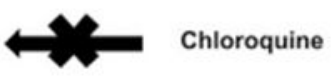
of LIFR

Fig. 3.

Increasing the Efficacy of LIF by Targeting LIFR Activity.

Excess activation by LIF triggers the phosphorylation of Ser1044 on LIFR by ERK1/2. Once LIFR is phosphorylated, it is endocytosed by the cell and degraded via the lysosomes.

Several drugs may be used to target this process, including PD98059, an ERK inhibitor and Chloroquine, an anti-malarial drug that inhibits lysosomal activity. 